\title{
Studying the Effect of MgO Addition on the Thermal and Electrical Properties for Iraqi Porcelain
}

\author{
Duraid Fawzi Mahdi \\ Applied Science Department, University of Technology, Baghdad-Iraq. \\ E-mail: Duraid_fawzi2000@yahoo.com
}

\begin{abstract}
The research was studied effect of addition Magnesium Monoxide $(\mathrm{MgO})$ on the thermal and electrical properties of Iraqi Porcelain with different weight percentages were $(0 \%, 5 \%, 10 \%, 17 \%$, $23 \%$ and $30 \%)$. The Porcelain was hard type and consist of (50\%wt) Kaolin, (25\%wt) Potassium Feldspar and (25\%wt) Flint and sieving process was achieved for all powders and the particle sizes were $(<125 \mu \mathrm{m}$ with $50 \% \mathrm{wt}),(<75 \mu \mathrm{m}$ with $35 \%$ wt $)$ and $(<250 \mu \mathrm{m}$ with $15 \% \mathrm{wt})$ for Kaolin. The other particle sizes were $(<75 \mu \mathrm{m})$ for Potassium Feldspar, $(<75 \mu \mathrm{m})$ for Flint and $(<63 \mu \mathrm{m})$ for $\mathrm{MgO}$. The powders were formed into disc shapes with diameters $(10 \mathrm{~mm})$ and $(40 \mathrm{~mm})$ by semi-dry pressing with (3 ton) applied pressure and Glycine (organic material) was added to powders through forming process with one drop to one gram from powder as a binder. The specimens were sintered in electrical furnace of $\left(1250^{\circ} \mathrm{C}\right)$ for $(2 \mathrm{hrs})$ as soaking time with increasing rate $7^{\mathrm{O}} \mathrm{C}$ for one minute. The Bulk Density, Apparent Porosity, Specific Heat Capacity, Thermal Conductivity, Thermo- Compressive Strength and Dielectric Strength were studied. The best results for Specific Heat Capacity and Thermal Conductivity are F mixture with $(30 \% \mathrm{MgO})$, Thermo- Compressive Strength is E mixture (23\% MgO) and Dielectric Strength is C mixture $(10 \% \mathrm{MgO})$.
\end{abstract}

[DOI: $10.22401 / \mathrm{JNUS} .20 .1 .11]$

Keywords: Traditional Ceramics, Advance Ceramics, Insulators, White wares, $\mathrm{MgO}$ and Porcelain.

\section{Introduction}

Porcelain is hard glazy white-ware made by a high temperature; generally consist of refined main raw materials which are clays as binders, feldspar as fluxes and flint as fillers. Porcelain is used for both art and technical fields with triaxial formation consist of 40$50 \%$ plastic base, $20-30 \%$ flux and $15-25 \%$ filler [1]. In 2009, Akinori Nagasawa and etl. Were studied the addition of iron oxide to dental porcelain material with weight percentages from $0.6 \%$ to $5.0 \%$. Slurry was placed on human enamel and dental porcelain surfaces, Nd:YAG laser was exposed with varying energy and exposure time periods. Melting of material occurred with conditions; $40 \mathrm{~W}$ for $4 \mathrm{~s}$ for $0.6 \%$ iron oxide, $20 \mathrm{~W}$ for $2 \mathrm{~s}$ for $2.5 \%$ and $5 \%$ iron oxide. However degradation of tooth substrate also was detected with high energy and extended exposure period [3]. In 2012, Arman Sedghi and etl. Were made higher strength porcelain as insulator for power industry by decreasing the Silica and increasing the alumina provides a higher mechanical strength in porcelain. They were used four types of fluxes which were nepheline syenite, Talc, manganese dioxide, and barium carbonate have been used to produce porcelain insulators with $30 \%$ alumina and then their electrical and mechanical properties have been investigated. The results have shown that among used fluxes adding $1 \%$ barium carbonate increases density to $2.7 \mathrm{~g} / \mathrm{cm} 3$, bending strength to 1608 $\mathrm{kg} / \mathrm{cm} 2$ and electrical strength up to $33 \mathrm{KV}$. Besides mullite and corundum peaks intensity when using $1 \%$ barium carbonate has been accomplished [7]. Currently three types of porcelain are distinguished in Europe: Hard, Vitreous and Bone Porcelain [2].

Hard porcelain as a rule is made from a batch composition consisting of $50 \%$ clay material, $25 \%$ feldspar and $25 \%$ flint fired at $\left(1250-1450^{\circ} \mathrm{C}\right)$. The fired body of hard porcelain, which is composed essentially of mullite $\left(\mathrm{Al}_{6} \mathrm{Si}_{2} \mathrm{O}_{13}\right)$, quartz and glass phase, exhibits a high transparency and high degree of whiteness. Hard porcelain resists melting for better than other kind of porcelain because it is fired at higher maturation temperature [1].

Vitreous porcelain differs from hard porcelain by its higher feldspar and quartz 
content, resulting in lower firing temperature. Accordingly, the values of the properties of vitreous porcelain do not correspond to high standard of hard porcelain. It was developed in Europe in an attempt to imitate the Chinese Hard Porcelain. Most of it is creamy- in tone, and some people prefer this color to pure white [2].

Bone porcelain is characterized by higher transparency, creamy white color, high degree of whiteness and good mechanical strength. As a rule the batch composition consist of 20-50\% bone ash, 20-45\% Cornish stone and $20-35 \%$ kaolin. The firing occurs in an oxidizing atmosphere at $\left(1200-1300^{\circ} \mathrm{C}\right)$ with short firing range and first firing step is the glazing. Because of the mixture composition deformation occur relatively frequently during firing [1].

Fig.(1) shows how mechanical strength, electrical strength and thermal shock resistance depend on the composition of the body. It is obvious that the best possible value of these three technically important properties cannot be attained in one and same body [4] Physical appearance of hard porcelain is high quality, dense body, and continental hardpaste white, vitrified translucent. The chemistry of hard porcelain is $\mathrm{SiO}_{2}$ (58-73 wt $\%), \mathrm{Al}_{2} \mathrm{O}_{3}(18-36 \mathrm{wt} \%), \mathrm{K}_{2} \mathrm{O}(1-8 \mathrm{wt} \%)$ and $\mathrm{CaO}$ (0-4 wt\%) [5]. Technical applications of hard porcelain are laboratory tools such as crucible, filtering funnel, mortar and ball mill [6]. Electrical capacitors and insulators are important applications for hard porcelain [5].

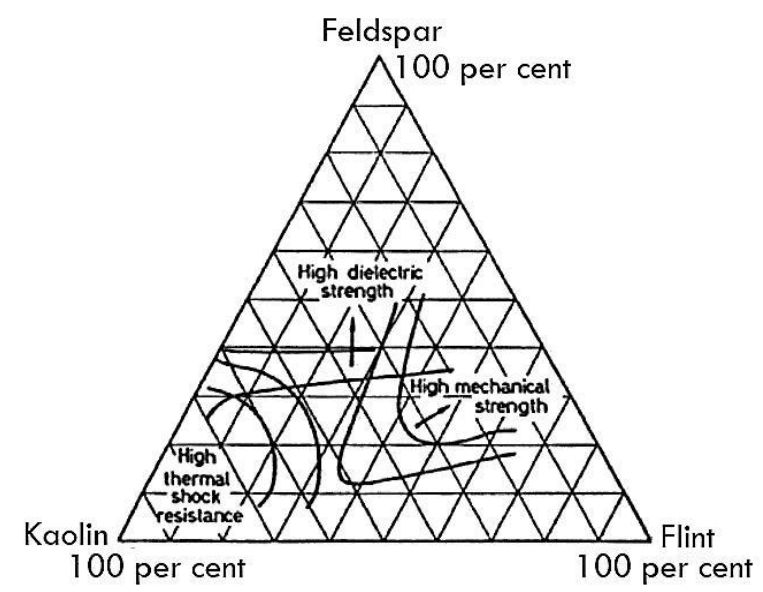

Fig.(1): Properties of Porcelain dependence on rational composition [4].
Magnesium oxide ( $\mathrm{MgO}$, magnesia) occurs naturally as the mineral periclase, a metamorphic mineral formed by the breakdown of dolomite, $\mathrm{CaMg}\left(\mathrm{CO}_{3}\right)_{2}$, and other magnesium minerals. The principal commercial sources of $\mathrm{MgO}$ are magnesite $\left(\mathrm{MgCO}_{3}\right)$ and magnesium hydroxide $\left[\mathrm{Mg}(\mathrm{OH})_{2}\right]$. The major application for magnesia is as a refractory lining in furnaces [1]. Magnesium oxide is very bulky white powder, known as light magnesium oxide [8]. The density of $\mathrm{MgO}$ is $3.58 \mathrm{gm} / \mathrm{cm}^{3}$ and insoluble in water. The crystalline structure of $\mathrm{MgO}$ is face center cubic and melting point is $2852^{\circ} \mathrm{C}$ with good thermal shock resistance [9].

\section{Experimental Work}

The work in this research is divide to many parts which are shown in Fig.(2) and these parts are:

\section{Materials}

The materials used in this research are:

\section{Porcelain}

The type of Porcelain was used in this research is Hard Porcelain type and consisting of following materials:

\section{Kaolin}

Kaolin clay is represent 50(wt\%) from hard porcelain body and used to produce traditional ceramics when the color of the finished object and its high temperature performance are important. The mineralogical composition of kaolinite $\left(\mathrm{Al}_{2} \mathrm{O}_{3} \quad 2 \mathrm{SiO}_{2} \quad 2 \mathrm{H}_{2} \mathrm{O}\right.$ is $46.6 \mathrm{wt} \%$ silica, $39.5 \mathrm{wt} \%$ alumina, and $13.9 \mathrm{wt} \%$ water) due to the presence of impurities [10]. The kaolin was used in this research is Iraqi Kaolin from Alduejlh Zone.

\section{Potassium Feldspar (Potash Feldspar)}

Potassium feldspar is represent 25(wt\%) from hard porcelain body. Potassium feldspar is a common name that applies to a group of minerals with a general chemical formula of $\mathrm{KAlSi}_{3} \mathrm{O}_{8} \quad\left(\mathrm{~K}_{2} \mathrm{O} \cdot \mathrm{Al}_{2} \mathrm{O}_{3} \cdot 6 \mathrm{SiO}_{2}\right)$. Potassium feldspar is usually white or very light in color and has a hardness of 6 on the mohs' scale of hardness and has good cleavage in two directions. The crystalline structure of 
potassium feldspar consists of an infinite network of $\mathrm{SiO}_{2}$ and $\mathrm{AlO}_{4}$ tetrahedra and the mineralogical composition of potassium feldspar can be expressed in term of the ternary system Orthoclase. Potassium feldspar is primarily used in industrial applications for their alumina and alkali content [11]. The potassium feldspar is used in this research from Alduejlh Zone too.

\section{Flint}

Flint is represent $25(\mathrm{wt} \%)$ from hard porcelain body. Flint has been used for the raw material for tools longer than any other material and fortunately it does not decay. Flint was formed in the chalk deposits; water percolated through the chalk and dissolved the silicon molecules within the chalk. Flint is consists primarily of $\mathrm{SiO}_{2} 43(\mathrm{wt} \%)$ and other oxides with different weight percentages such as $\mathrm{Al}_{2} \mathrm{O}_{3}, \mathrm{Fe}_{2} \mathrm{O}_{3}, \mathrm{CaO}, \mathrm{MgO}, \mathrm{K}_{2} \mathrm{O}, \ldots$ etc [3]. The flint was used in this research from Bauxite location in the west desert of Al-Inbar state.

\section{Magnesium Oxide (MgO)}

Magnesium oxide or magnesia is a white hygroscopic solid mineral that occurs naturally as periclase and is a source of magnesium. It has an empirical formula of $\mathrm{MgO}$ and consists of a lattice of $\mathrm{Mg}^{2+}$ and $\mathrm{O}^{2-}$ ions held together by ionic bonding. $\mathrm{MgO}$ a refractory material is one that is physically and chemically stable at high temperatures [9]. $\mathrm{MgO}$ was used in this research is made by $\mathrm{BDH}$ chemicals Ltd poole-England with purity $96 \%$.

\section{Crushing and Milling}

The Iraqi flint, potassium feldspar and kaolin stones are converting to powders by using Retsch Jaw Crusher (Germany). Then the small aggregates are converting to fine powders by using porcelain ball mill (Baird \& Tatlock) (UK) with 22 porcelain balls for 24 hours in run with medium velocity.

\section{Sieving Process}

The fine powders are sieving in different sieve sizes by using Retsch Sieving Machine Germany made. The using particle sizes are P.S. $<75 \mu \mathrm{m}(35 \mathrm{wt} \%)$, P.S. $<125 \mu \mathrm{m}(50$ $w t \%)$ and P.S. $<250 \mu \mathrm{m}(15 \mathrm{wt} \%)$ for Iraqi kaolin fine powder, P.S. $<75 \mu \mathrm{m}$ for potassium feldspar fine powder, P.S. $<75 \mu \mathrm{m}$ for flint fine powder and P.S. $<63 \mu \mathrm{m}$ for $\mathrm{MgO}$ fine powder. The sieving process was running for 6 hours with discontinuous mode.

\section{Mixing Process}

The total weight of sample is $(20 \mathrm{gm})$ and the research is making six batches with different addition of $\mathrm{MgO}$ which are $(0 \mathrm{wt} \%, 5$ $\mathrm{wt} \%, 10 \mathrm{wt} \%, 17 \mathrm{wt} \%, 23 \mathrm{wt} \%$ and $30 \mathrm{wt} \%)$. The weights and percentages of all batches were used in this research are shown in Table(1). By using digital balance with two digits, all different batches are weighs according to weigh percentages of addition $\mathrm{MgO}$ and mixed by manual porcelain mortar. Through mixing process, an organic material powder is term "Glycine" with formula $\left(\mathrm{NH}_{2} \mathrm{CH}_{2} \mathrm{COOH}\right)$ was dissolving in distills water with ratio 1 gram glycine powder/ $4 \mathrm{ml}$ distill water. It was added to all batches with ratio 1 drop/ 1 gram from batch as a binder which helpful in forming process. The good mixing is done when grinding and stirring is be good and all the different powders are interfering and become one powder with one color as obvious for eye. 


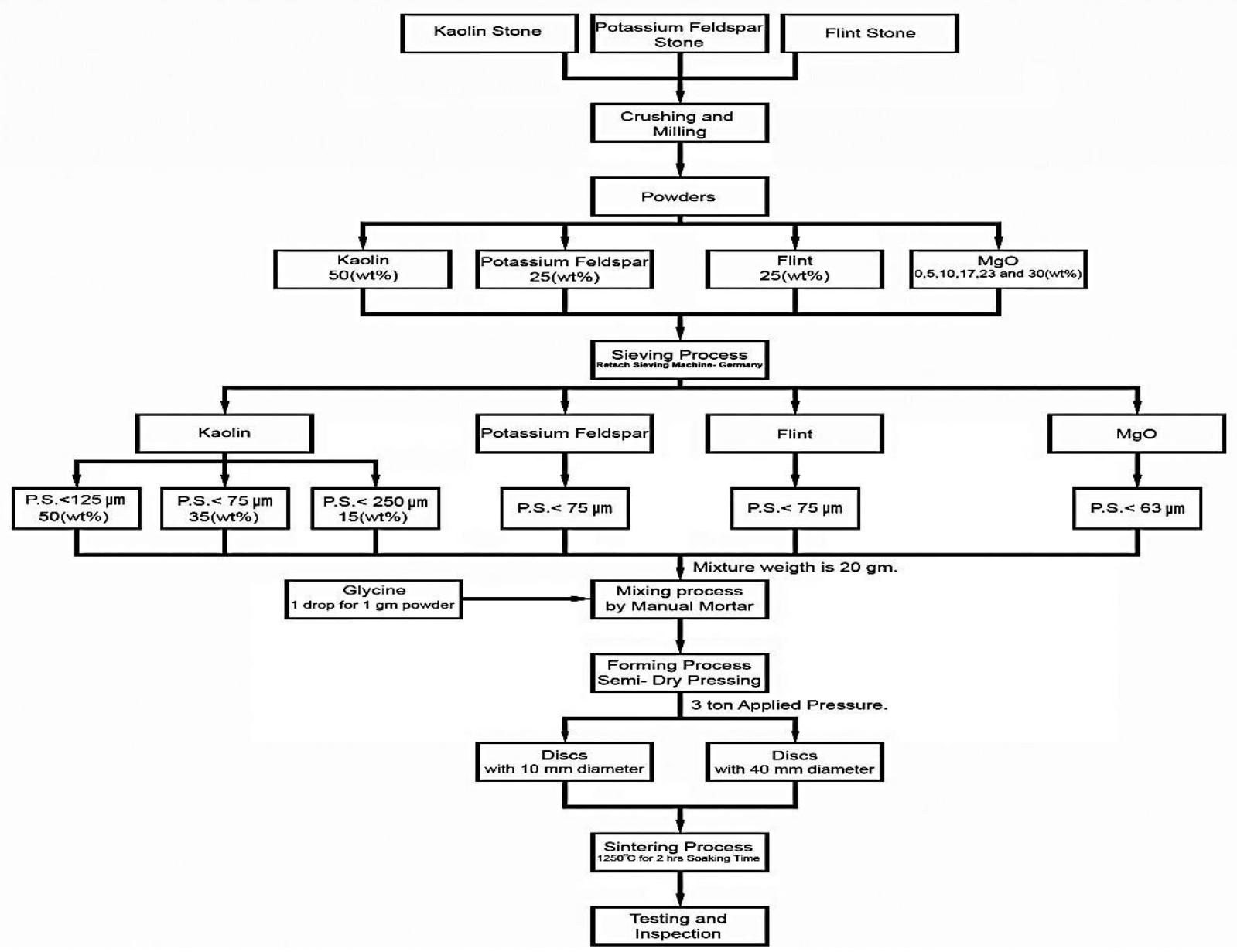

Fig.(2): The block diagram of experimental work.

Table (1)

Batch Weights.

\begin{tabular}{|c|c|c|c|c|c|c|c|}
\hline \multirow{4}{*}{ Batch } & \multicolumn{2}{|r|}{$\mathrm{MgO}$} & \multicolumn{5}{|c|}{ Porcelain(weights gm) } \\
\hline & \multirow{3}{*}{ wt\% } & \multirow{3}{*}{$\begin{array}{l}\text { Weight }(\mathrm{gm}) \\
\text { P.S. }<63 \mu \mathrm{m}\end{array}$} & \multicolumn{3}{|c|}{ Kaolin (50 wt\%) } & \multirow{3}{*}{ 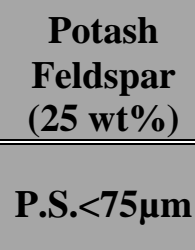 } & \multirow{3}{*}{$\begin{array}{c}\begin{array}{c}\text { Flint } \\
(25 \mathrm{wt} \%)\end{array} \\
\text { P.S. }<75 \mu \mathrm{m}\end{array}$} \\
\hline & & & P.S. $<125 \mu \mathrm{m}$ & P.S. $<75 \mu \mathrm{m}$ & P.S. $<250 \mu \mathrm{m}$ & & \\
\hline & & & $50 \mathrm{wt} \%$ & $350 w t \%$ & $15 \mathrm{wt} \%$ & & \\
\hline$\overline{\mathrm{A}}$ & $\overline{0}$ & 0 & $\overline{5}$ & 3.5 & 1.5 & $\overline{5}$ & $\overline{5}$ \\
\hline B & 5 & 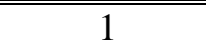 & 5 & 3.5 & 1.5 & 5 & 5 \\
\hline $\mathrm{C}$ & 10 & 2 & 5 & 3.5 & 1.5 & $\overline{5}$ & $\overline{5}$ \\
\hline $\mathrm{D}$ & 17 & 3.4 & $\overline{5}$ & 3.5 & 1.5 & 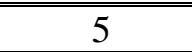 & 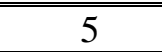 \\
\hline $\mathrm{E}$ & 23 & 4.6 & 5 & 3.5 & 1.5 & 5 & 5 \\
\hline $\mathrm{F}$ & 30 & 6 & 5 & 3.5 & 1.5 & 5 & 5 \\
\hline
\end{tabular}

\section{Forming Process}

The semi-dry pressing method was used by manual hydraulic press and steel dies of diameters $10 \mathrm{~mm}$ and $40 \mathrm{~mm}, 12$ specimens were produced with diameter $10 \mathrm{~mm}$ and weight of one specimen is $1.3 \mathrm{gm}$ for one batch. One specimen was produced form diameter $40 \mathrm{~mm}$ with weight $5 \mathrm{gm}$ for one batch. The applied pressure was 3 ton under 15 sec. for all specimens.

\section{Sintering Process}

By using Nabertherm furnace (Germany made), the rate of increasing temperature was $7^{\circ} \mathrm{C} / \mathrm{min}$ to avoid the cracks that could be happen throughout crystalline water vapored 
and phase transformations. Starting increasing furnace temperature along process until reach to the $1250^{\circ} \mathrm{C}$, the time was $2 \mathrm{hrs}$. The socking time was 2 hours and then the furnace was off cooling to the room temperature.

\section{Bulk Density}

Bulk density is defined as the mass (weight) of the dry solids divided by the total volume of the wet sample; that is, bulk density is the ratio of the mass of the mineral grains to the total volume. All index properties are essentially ratios of masses and volumes. Therefore, bulk density can be calculated directly from mass and volume measurements, or by relationships with other index properties. The equation for bulk density is [12]:

$$
\rho=\frac{M}{\mathrm{~V}}
$$

Where $\rho$ bulk density $\left(\mathrm{gm} / \mathrm{cm}^{3}\right), \mathrm{M}$ is is mass of specimen $(\mathrm{gm})$ and $\mathrm{V}$ is volume of specimen $\left(\mathrm{cm}^{3}\right)$.

\section{Apparent Porosity}

It is a measure of the effective open pore space in the ceramic body into which the water, liquid, gas and other solutions can penetrate and thereby contribute to eventual degradation of the structure. The porosity of ceramic body is expressed as the average percentage of open pore space in the overall ceramic body volume. The specimens were immersed in pool of water for $24 \mathrm{hrs}$ and their weights were measured as wet weight, dry weight and hanging weight in water in gram units. The equation for apparent porosity is [13]:

$$
\begin{aligned}
& \mathcal{V}=S-\mathrm{I} \\
& P \%=\frac{\mathrm{S}-D}{\mathcal{V}} \times 100
\end{aligned}
$$

Where $\mathrm{P} \%$ is apparent porosity, $\mathcal{V}$ is exterior volume, $\mathrm{S}$ is wet weight of specimen (gm), I is hanging weight of specimen in water (gm) and D is dry weight of specimen (gm).

\section{Specific Heat Capacity}

The method of mixtures used in this test method consists essentially a known mass of material is heating at certain temperature and put in a known mass of water which temperature is low and determining the equilibrium temperature that result. The heat absorbed by the water and the containing vessel can be calculated and this value equated to the expression for the heat given up by the hot material. From this equation the unknown specific heat capacity can be calculated [14]:

$$
\begin{aligned}
& \mathrm{m}_{\mathrm{s}} \cdot \mathrm{c}_{\mathrm{ps}}\left(\mathrm{T}_{\mathrm{s}}-\mathrm{T}_{2}\right)=\mathrm{m}_{\mathrm{w}} \cdot \mathrm{c}_{\mathrm{pw}}\left(\mathrm{T}_{2}-\mathrm{T}_{1}\right)+\mathrm{m}_{\mathrm{c}} \cdot \mathrm{c}_{\mathrm{pc}} \\
& \left(\mathrm{T}_{2}-\mathrm{T}_{1}\right)
\end{aligned}
$$

Where $\mathrm{m}_{\mathrm{s}}$ is the mass of specimen $(\mathrm{gm}), \mathrm{c}_{\mathrm{ps}}$ is specific heat capacity for specimen $\left(\mathrm{J} / \mathrm{gm} .{ }^{\mathrm{O}} \mathrm{C}\right), \quad \mathrm{T}_{\mathrm{s}}$ is temperature of heated specimen $\left(100^{\circ} \mathrm{C}\right)$ before putting inside the calorimeter, $\mathrm{T}_{2}$ is final temperature after putting the heated specimen inside calorimeter, $T_{1}$ is the initial temperature of water, $m_{w}$ is the mass of water $(\mathrm{gm}), \mathrm{c}_{\mathrm{pw}}$ is the specific heat capacity of water $\left(4184 \mathrm{~J} / \mathrm{gm} .{ }^{\mathrm{O}} \mathrm{C}\right), \mathrm{m}_{\mathrm{c}}$ is the mass of calorimeter $(\mathrm{gm})$ and $\mathrm{c}_{\mathrm{pc}}$ is the specific heat capacity of calorimeter $\left(0.385 \mathrm{~J} / \mathrm{gm} .{ }^{\circ} \mathrm{C}\right)$.

\section{Thermal Conductivity}

Thermal conductivity is defined as the property of a material's ability to conduct heat as a result of temperature difference under steady state boundary condition. Thermal conductivity is determined by Lee's Disc method which the specimen put between two brass discs and the heater is supplied by electric current from power supply. When the two temperature of the two brass discs are stable in certain temperature and do not increasing over, the difference between two temperatures is recording and thermal conductivity is calculated from the following [15]:

$\mathrm{I} . \mathrm{V}=\pi r^{2} \mathrm{e}\left(T_{A}+T_{B}\right)+2 \pi r e\left[d_{A} T_{A}+\right.$ $\left.d_{S} \frac{1}{2}\left(T_{A+} T_{B}\right)+d_{B} T_{B}+d_{C} T_{C}\right]$

$K\left(\frac{T_{B}-T_{A}}{d_{S}}\right)=e\left[T_{A}+\frac{2}{r}\left(d_{A}+\frac{1}{4} d_{S}\right) T_{A}+\right.$ $\left.\frac{1}{2 r} d_{S} T_{B}\right]$

Where $\mathrm{K}$ is thermal conductivity $\left(\mathrm{W} / \mathrm{m} .{ }^{\mathrm{O}} \mathrm{C}\right)$, $\mathrm{T}_{\mathrm{A}}, \mathrm{T}_{\mathrm{B}}$ and $\mathrm{T}_{\mathrm{C}}$ are temperatures of $\mathrm{A}, \mathrm{B}$ and $\mathrm{C}$ brass discs, $d_{A}, d_{B}$ and $d_{C}$ are thicknesses of brass discs $(\mathrm{mm}), \mathrm{d}_{\mathrm{S}}$ is thickness of specimen $(\mathrm{mm}), \mathrm{r}$ is radius of brass discs $(\mathrm{mm}), \mathrm{I}$ is the pass electric current $(0.25 \mathrm{~A}), \mathrm{V}$ is supply voltage $(6 \mathrm{~V})$. 


\section{Thermo-Compressive Strength}

Thermal shock was made for specimens in different temperatures which are $100^{\circ} \mathrm{C}$, $250^{\circ} \mathrm{C}$ and $450^{\circ} \mathrm{C}$ for $15 \mathrm{~min}$ stay in these different temperatures and cooling rapidly in cold water with temperature $3^{\mathrm{O}} \mathrm{C}$ for one time. After thermal shock was made the shocking specimens are put under load to test compressive strength and how the value of compressive strength is become. Compressive strength is one of must use modifiers to be specific and it is mean the applied load on area of cross-section of specimen and it is circle certainly. The specimen is a cylindrical shape put under load with $\mathrm{MPa}$ units and the equation of compressive strength is [13]:

$$
\sigma=\frac{\mathrm{F}}{\mathrm{A}}
$$

Where $\sigma$ is compressive strength in $\mathrm{MPa}$ unite, $\mathrm{F}$ is load in $\mathrm{N}$ unite and $\mathrm{A}$ is area of circle in $\mathrm{m}^{2}$ unite.

\section{Dielectric Strength}

Dielectric strength is a measure of the maximum electrical field strength that a material can withstand, after which electrical (dielectric) breakdown occurs. The failure is usually in the form of a carbonized puncture through the material, and as a result the material permanently loses its dielectric properties. The specimen with area $2 \mathrm{~cm}^{2}$ at least and no more than $1 \mathrm{~cm}$ of thickness put in pool of BAUR voltage breakdown testerEngland filling with viscos oil which has high dielectric strength between two pin of brass. The voltage breakdown tester is begin to increase the voltage until to breakdown in specimen is occur. The equation of dielectric strength is [16]:

$$
D S=\frac{\mathrm{V}}{\mathrm{T}} \text {. }
$$

Where DS is dielectric strength in $\mathrm{Kv} / \mathrm{mm}$, $\mathrm{V}$ is breakdown voltage in $\mathrm{Kv}$ and $\mathrm{T}$ is the thickness of specimen in $\mathrm{mm}$.

\section{Result and Discussion Bulk Density}

The increasing of weight percentage of $\mathrm{MgO}$ in the hard porcelain body lead to decreasing in bulk density as shown obviously in Fig.(3). But this case does not meaning decrease in bulk density actually; because of the bulk density of $\mathrm{MgO}\left(3.58 \mathrm{gm} / \mathrm{cm}^{3}\right)$ is higher than bulk density of hard porcelain (2.4 $\mathrm{gm} / \mathrm{cm}^{3}$ ). Theoretically, the bulk density of hard porcelain is increasing when weight percentage of $\mathrm{MgO}$ is increasing, but does not occur because of increasing of porosity percentage with bulk density is more than increasing of bulk density for hard porcelain, especially at last three weight percentage of $\mathrm{MgO}$. The some of $\mathrm{MgO}$ particles are interface with create glass phase through sintering process and reaction is happen and restricted the diffusion of glass phase in whole hard porcelain body. This is leave pores in some regions of hard porcelain body and increase with $\mathrm{MgO}$ weight percentage.

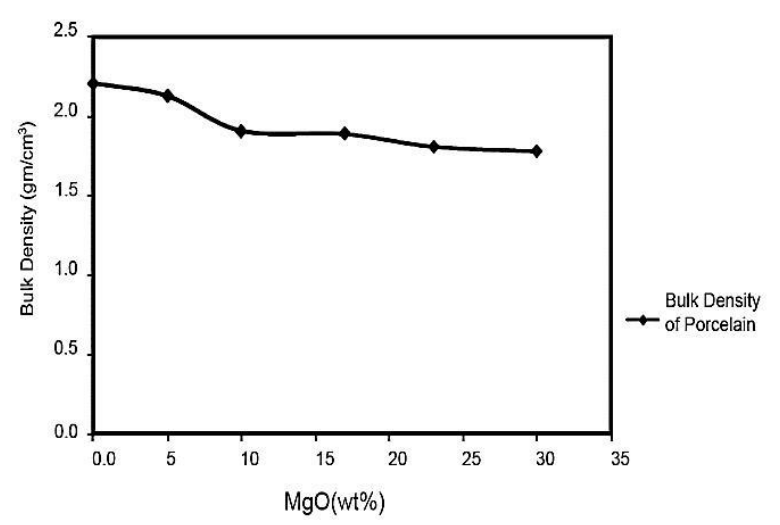

Fig.(3): The bulk density of hard porcelain with $\mathrm{MgO}$ wt\%.

\section{Apparent Porosity}

As we seen in Fig.(4) which is prove our pervious speak when increasing of $\mathrm{MgO}$ weight percentage in hard porcelain body the value of apparent porosity is increasing obviously. This evidence on create the pores and increasing their percentage throughout reaction with some of $\mathrm{MgO}$ particles which decrease from movement of glass phase diffusion in hard porcelain body through sintering process. The wastes of $\mathrm{MgO}$ Particles are restricted fusion of hard porcelain constituents with each other because of small particle size of $\mathrm{MgO}$ and high bulk density, so that the movement of atomic diffusion of hard porcelain constituents and reaction with each other become more difficult. This lead to create more pores and vacancies in hard porcelain body. 


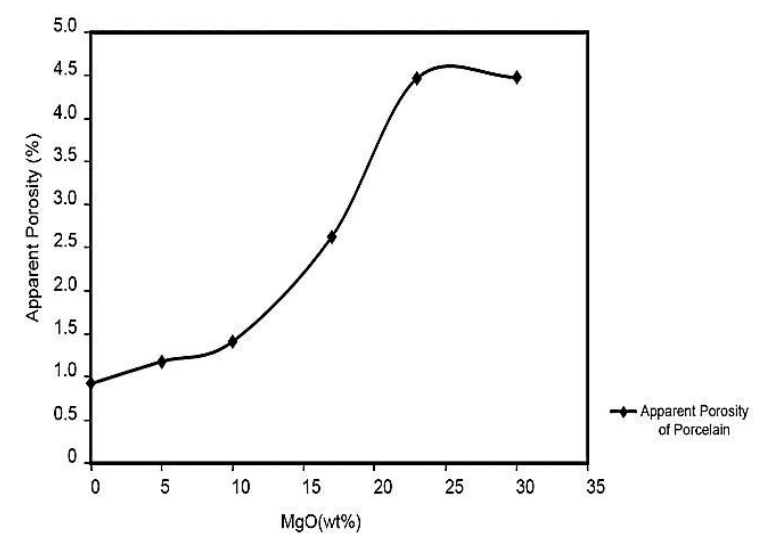

Fig.(4): Apparent porosity of hard porcelain with $\mathrm{MgO}$ wt\%.

\section{Specific Heat Capacity}

Fig.(5) is indicating the increasing in value of specific heat capacity for hard porcelain when addition of $\mathrm{MgO}$ weight percentage is increasing. This increasing is true, because of the theoretical specific heat capacity of $\mathrm{MgO}$ with value $\left(1.03 \mathrm{~J} / \mathrm{gm} .{ }^{\mathrm{O}} \mathrm{C}\right)$ higher than the theoretical specific heat capacity of hard porcelain with value $\left(0.92 \mathrm{~J} / \mathrm{gm} .{ }^{\mathrm{O}} \mathrm{C}\right)$. The increasing is lead to increase in thermal potential energy of hard porcelain body with reduce in consumed energy for generated thermal.

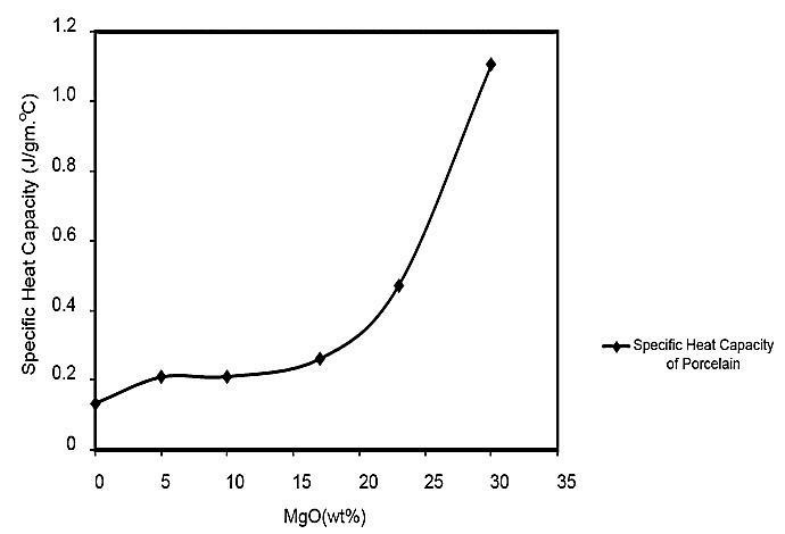

Fig.(5): Specific heat capacity of hard porcelain with $\mathrm{MgO}$ wt\%.

\section{Thermal Conductivity}

The increasing of pore and vacancy quantities which are result from increasing in $\mathrm{MgO}$ weight percentage addition and lead to decreasing in the value of hard porcelain thermal conductivity as shown in figure obviously. This case is increasing ability to thermal insulation of hard porcelain and more thermal saving with reduce of heat transfer by conduction mode through hard porcelain body.

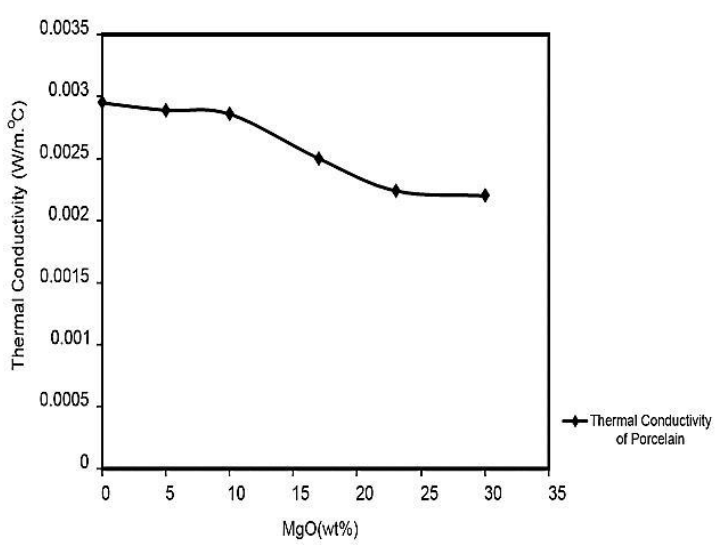

Fig.(6): Thermal conductivity of hard porcelain with $\mathrm{MgO}$ wt\%.

\section{Thermo-Compressive Strength}

The increasing of $\mathrm{MgO}$ weight percentage addition due to increasing in compressive strength for three thermal declines $\left(100-3^{\circ} \mathrm{C}\right)$, $\left(250-3^{\mathrm{O}} \mathrm{C}\right)$ and $\left(450-3^{\mathrm{O}} \mathrm{C}\right)$. The Fig. (7) is indicating the increasing of compressive strength is not continuous; the increasing of compressive strength is reach to certain weight percentage of $\mathrm{MgO}$ addition. The thermal decline (100-3OC), the increasing of compressive strength value is reach to about $17 \%$ from weight percentage of $\mathrm{MgO}$ addition and after this weight percentage decreasing is begins. In two thermal declines $\left(250-3^{\mathrm{O}} \mathrm{C}\right)$ and $\left(450-3^{\mathrm{O}} \mathrm{C}\right)$, the increasing of compressive strength value is reach to about $23 \%$ from weight percentage of $\mathrm{MgO}$ addition and after this weight percentage decreasing is begins too. The reason of this case is increasing of bulk density of hard porcelain when weight percentage of $\mathrm{MgO}$ addition is increasing to $17 \%$ in thermal decline $\left(100-3^{\circ} \mathrm{C}\right)$ and $23 \%$ in two thermal declines $\left(250-3^{\circ} \mathrm{C}\right)$ and $\left(450-3^{\mathrm{O}} \mathrm{C}\right)$. Here the bulk density of hard porcelain is stopping and apparent porosity is begin to increasing, so that the value of compressive strength is begin to decreasing for hard porcelain. 


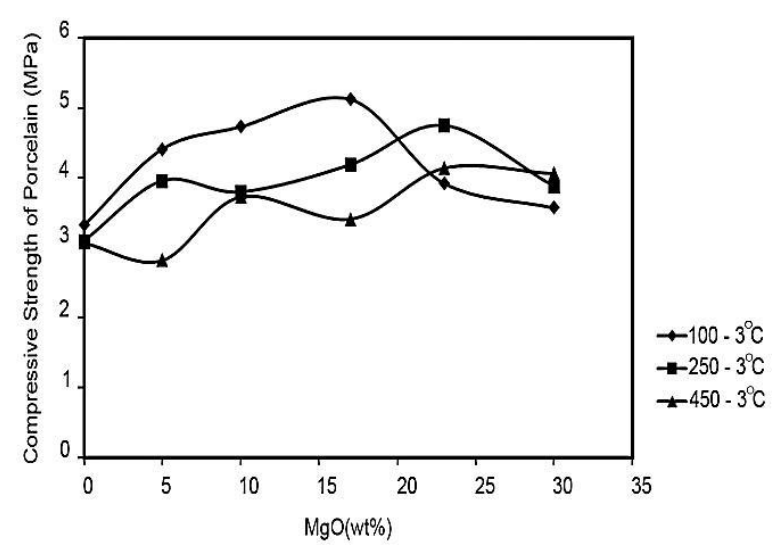

Fig.(7): Thermo-compressive strength of hard porcelain with $\mathrm{MgO}$ wt\%.

\section{Dielectric Strength}

The dielectric strength of hard porcelain is increasing when weight percentage of $\mathrm{MgO}$ addition is increasing until reach to about $10 \%$ from weight percentage of $\mathrm{MgO}$ and after this weight percentage the decreasing of dielectric strength of hard porcelain is decreasing. As shown in Fig.(8), the cause is belong to the increasing of densification and reaction for create glass phase throughout sintering process in the spread regions of $\mathrm{MgO}$ particles. The densification and reaction with glass phase is reducing and create percentage of pores and vacancies are become more after $10 \%$ from weight percentage of $\mathrm{MgO}$ addition. For this reason, the dielectric strength of hard porcelain is decreasing because of the dielectric strength is inverse proportional to the create pores and vacancies in the ceramic body generally and hard porcelain particularly.

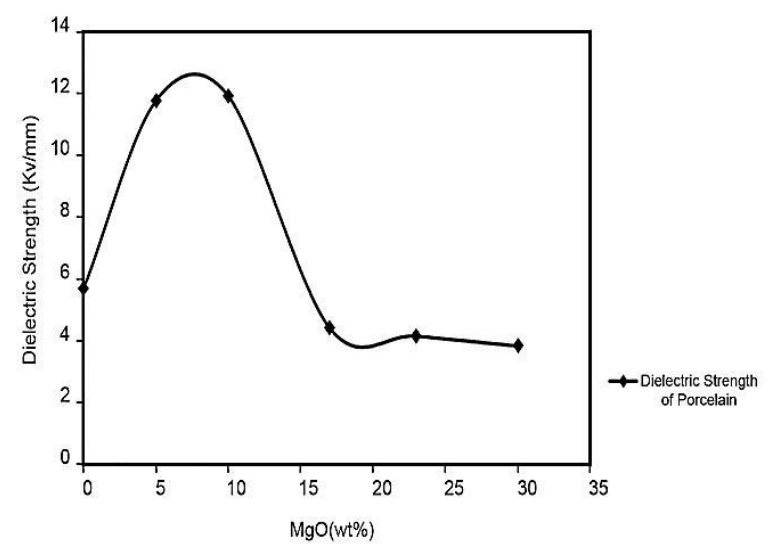

Fig.(8): Dielectric strength of hard porcelain with $\mathrm{MgO}$ wt\%.

\section{Conclusion}

The addition increasing of $\mathrm{MgO}$ to hard porcelain show improvement in the some properties and certain limit to other properties:

1. Mullite which came from combination of $72 \% \mathrm{Al}_{2} \mathrm{O}_{3}$ and $28 \% \mathrm{SiO}_{2}$ and the Mullite phase has good mechanical properties.

2. Quartz is other phase is creating through sintering process above $1000^{\circ} \mathrm{C}$ and it is crystalline form of silica and it has stable physical and chemical properties at room and higher temperatures.

3. A few of Cristobalite is also create phase in sintering process at $1250^{\circ} \mathrm{C}$ and another form of silica with isostructural polymorphs (cubic ice) and good thermal properties.

4. Glass phase is other create phase in sintering process which is consist of combination of silica with other oxides and work as binder for hard porcelain body lead to raise mechanical properties of hard porcelain and reduce from pores and vacancies.

5. Some particles of add $\mathrm{MgO}$ is reaction with silica create phase of magnesium silicates $\left(\mathrm{MgSiO}_{3}\right)$ raising from mechanical properties.

6. $\mathrm{MgO}$ particles are reaction with glass phase and made it more dense and viscos lead to raise bulk density and apparent porosity in same time.

7. The rest of add $\mathrm{MgO}$ particles are become waste in hard porcelain body causing increasing in pores and vacancies.

8. The research is show the best batches which are $\mathrm{F}(30 \mathrm{wt} \% \mathrm{MgO}$ ) for thermal conductivity and specific heat capacity properties, E (23 wt\% MgO) for thermocompressive strength property and $\mathrm{C}$ (10 $\mathrm{wt} \% \mathrm{MgO}$ ) for dielectric strength property.

9. It is possible to use other additives such as $\mathrm{CaO}, \mathrm{Cr}_{3} \mathrm{O}, \mathrm{SiC}, \mathrm{TiO}_{2}, \mathrm{ZrO}_{2}$, Chromite $\left(\mathrm{FeO} . \mathrm{Cr}_{2} \mathrm{O}_{3}\right)$ in order to development and improvement the thermal and electrical properties for hard porcelain. 


\section{References}

[1] Leonard D. Akwilapo and Kjell Wiik, "Ceramic Properties of Pugu Kaolin Clays. PART 2: Effect of Phase Composition on Flexural Strength", Chemical Society of Ethiopia, 18(1), 7-16, 2004.

[2] Wardell S., "Porcelain and Bone China", Crowood Press (pub), ISBN, 176, 2004.

[3] Akinori Nagasawa, Hiroyasu Koizumi, Daisuke Nakayama, Hiromasa Kazama, Hideo Matsumura and Koji Nishikawa, "Fusion of Inorganic Materials to Enamel and Porcelain Surfaces with Nd:YAG Laser", International Chinese Journal of Dentistry, 9(1), 19-22, 2009.

[4] Budnikov, "The Technology of Ceramic and Refractories", Published Paper, The M.I.I. press, Cambridge, Mass, 647, 1964.

[5] E. Kamseu, C. Leonelli, D.N. Boccaccini, P. Veronesi, P. Miselli, Giancarlo Pellacani and U. Chinje Melo, "Characterization of porcelain compositions using two china clays from Cameroon", ElSEVIER, Ceramics International, 33(1), 851-857, 2007.

[6] Ceram Tec AG, The ceramic experts, "Hard Porcelain and Special Ceramic Products for Laboratory and Engineering Applications", Innovation Ceramic Engineering, Chemical Applications Division, 2013.

[7] Arman Sedghi, Naser Hamidnezhed and Nastaran Riahi Noori, "The Effect of Fluxes on Alumina Silicate Porcelain Insulator Properties and Structure", International Conference on Ecological, Environmental and Biological Sciences (ICEEBS 2012), Jan 7-8, Dubai, 343-345, 2012.

[8] JECFA, Metals and Arsenic Specifications, "Magnesium Oxide", Published paper and revised at the $57^{\text {th }}$, USA, 2001.

[9] Wikipedia (Free Encyclopedia), "Magnesium Oxide", 2016.

[10] James F. Shackelford and Robort H. Doremus, "Ceramic and Glass Materials, Structures, Properties and Processing", Springer, 119-120, 2008.

[11] Dr. Kamar Shah Ariffin, "Feldspathic Minerals", EBS425/3 Mineral
Perindustrain, Disediakan Oleh, India, 1-2, 2003.

[12] Kathleen A. Dadey \& et., "Dry-Bulk Density: It's use and Determination", Proceeding of the Ocean Drilling Program, Scientific Results, 126(1), 551, 1992.

[13] Huda Hussein, "Improvement of Bauxite by using Micro and Nano $\mathrm{SiC}$ and $\mathrm{Al}_{2} \mathrm{O}_{3}$ ", Doctoral thesis, Applied Sciences, University of Technology, Baghdad-Iraq, 19, 2014.

[14] ASTM C351-92b, "Standard Test Method for Mean Specific Heat of Thermal Insulation", Annual Book of ASTM Standard, 2002-2004.

[15] Paul Philip and Layi Fagbenle, "Design of Lee's Disc Electrical Method For Determining Thermal Conductivity of A poor Conductor in Form of A flat Disc", International Journal of Innovation and Scientific Research, 9(2), 335-343, 2014.

[16] Matthew J. Thompson, David C. Whalley and Neil Hopkinson, "Investigating Dielectric Properties of Sintered Polymers for Rapid Manufacturing", Department of Mechanical and Manufacturing Engineering, Loughborough University, UK, 82, 2008.

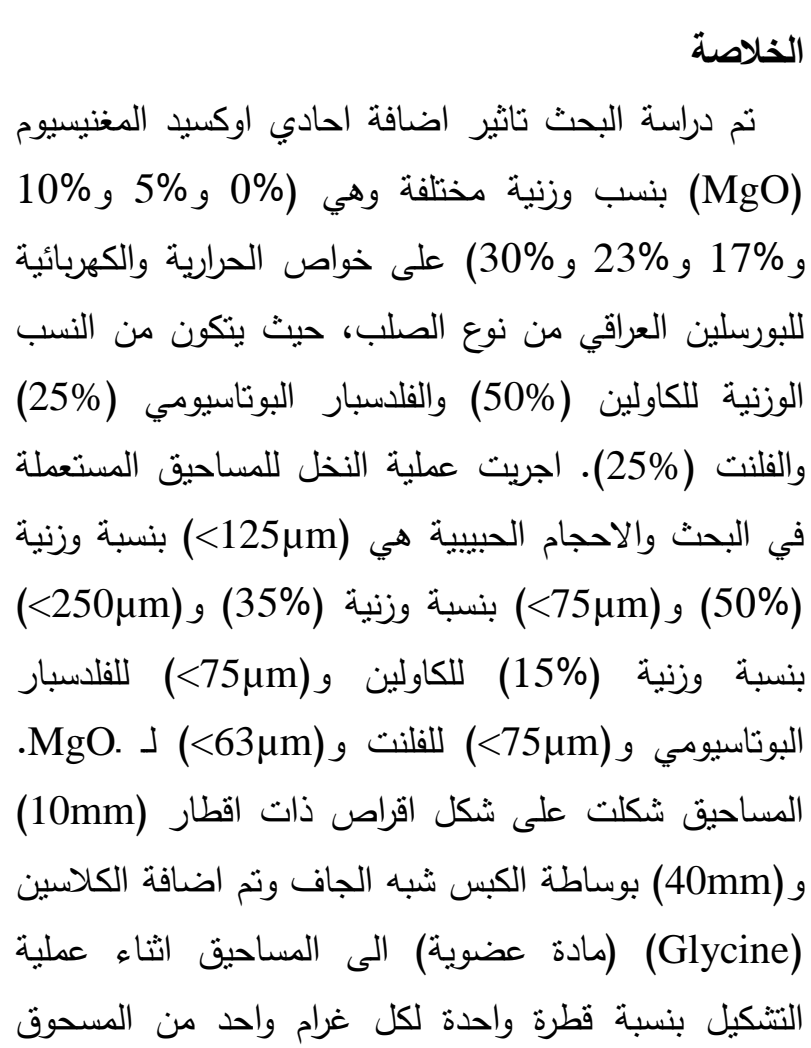


كمادة رابطة. تم تلبيذ العينات بفرن كهربائي بدرجة حرارة (ولمدة ساعتين (وقت الانضاج) وبمعدل صعود ( لدقيقة الواحدة. جرى اختبار الكثافة والمسامية الظاهرية والسعة الحرارية النوعية والتوصيلية الحرارية ومقاومة الانضغاط - الحراري ومتانة العزل الكهربائي لعينات البورسلين. نتائج البحث اظهرت ان افضل خلفئه خلطة هي (30\%MgO) F والتوصيلية الحرارية والخلطة EMgO) E للمقاومة الانضغاط- الحراري والخلطة CMgO) C

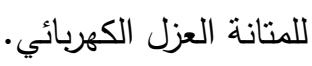

الكلمات المفتاحية: السيراميك التقليدي والسيراميك المتقدم والعوازل والخزف الابيض و MgO والبورسلين. 